\title{
Learning Model using the VCT Digital Modules
}

\author{
Sri Yunita ${ }^{1}$, Sri Hadiningrum ${ }^{2}$, Sugiharto ${ }^{3}$ \\ \{ sriyunitasugiharto@gmail.com ${ }^{1}$, hadiningrum1309@gmail.com², \\ sugihgeo.unimed@gmail.com\} \\ 1,2,3 Universitas Negeri Medan, Jl. Willem Iskandar Pasar V Medan, Indonesia
}

\begin{abstract}
This article aims to describe the results of research in the form of 1) developing learning models on the anti-corruption subject through the use of VCT digital module; 2) developing lesson plan on anti-corruption subject through the use of VCT digital module; 3) developing assessment of learning outcomes in anti-corruption subject using VCT digital modules. This study uses a development research method using stages adapted from the Borg \& Gall model, namely: 1) a preliminary study; 2) research planning; 3) initial product development; 4) field trial I; 5) revision of the results of trial I; 6) field trial II; 7) revision of trial results II; 8) due diligence; 9) revision of the results of the due diligence and 10) dissemination of the final product. The study was implemented at the PPKn department of the Faculty of Social Sciences UNIMED. The outputs generated from this study are 1) learning models on the anti-corruption subject through the use of VCT digital module; 2) lesson plan on the anti-corruption subject through the use of VCT digital module; 3 ) assessment of learning outcomes in the anticorruption subject using the VCT digital module.
\end{abstract}

Keywords: Module, Digital, Value Clarification Technique.

\section{Introduction}

Corruption in Indonesia has reached an alarming stage. Based on the 2018 Corruption Perceptions Index report (www.transparency.org/cpi) Indonesia is ranked 89 out of 180 countries. Although this ranking is better than in previous years, the ranking of corruption in Indonesia is far above that of neighboring countries such as Malaysia at 61 or Singapore at number 3 . The rise of corruption has affected economic damage and stunted development. If it continues to be tolerated, the Indonesian nation will suffer even more in poverty, ignorance, and underdevelopment. The corruption eradication in Indonesia is not only done through law enforcement, but preventive action needs to be taken as early as possible. One way that can be done is through education to create an anti-corruption generation. Anticorruption education is expected to be able to foster awareness and real action among students not to tolerate the slightest act of corruption.

Seeing the importance of corruption education in schools and colleges, there need to be efforts from educators to create meaningful, effective and fun anti-corruption learning. One of them is using learning-based digital modules which are oriented towards character building such as the Value Clarification Technique learning model. The purpose of this study is: (1) develop anti-corruption learning models through the use of digital modules based on VCT learning models, (2) develop and develop anti-corruption learning tools through the use of digital modules based on VCT learning models, and (3) developing anti-corruption learning 
outcomes assessment and anti-corruption attitude of students majoring in Citizenship education FIS UNIMED.

\section{Literature review}

Anti-corruption education is an education program on corruption that aims to build and increase citizens' awareness of the dangers and consequences of acts of corruption. The main target of anti-corruption education is to introduce the phenomenon of corruption which includes criteria, causes, and consequences, increasing intolerance towards acts of corruption, demonstrating various possibilities of efforts to fight corruption and contributing to established standards such as realizing values and capacities to fight corruption among young generations [1]

The need for anti-corruption education has become part of national education as stated in the regulation of the minister of national education (Permendiknas) No.22 and No. 23 of 2003 concerning content standards and standards of competence of graduates for primary and secondary education units. In the Permendiknas it is stated that the development of anticorruption attitudes and behavior is part of the curriculum in the field of Citizenship Education (Civics) studies. Dharma states that in general the objectives of anti-corruption education are: (1) the formation of knowledge and understanding of the forms of corruption and its aspects; (2) changing perceptions and attitudes towards corruption; and (3) the formation of new skills and skills aimed at fighting corruption [2]

Although it has the main target as a value education it still covers the three areas of education as stated by Bloom in the development of cognitive, affective and psychomotor aspects of students. So that anti-corruption behavior can become a character, then several steps can be taken in anti-corruption education, including: (1) train students to determine their behavior choices. Learners must be told about the rights, obligations, and consequences of the actions they do. Based on these choices students can determine which is good or bad. If students can make their own decisions based on the choices they make, then they also dare to say no or yes to something, (2) allow developing a broad understanding by creating flexible situations where students can collaborate, share, and obtain the guidance needed from educators. Therefore, activities in analyzing cases, discussions, role-playing or interviews are situations that will develop the character of corruption in students, and (3) involve students in various social activities in their environment. This is intended to instill a sense of responsibility and respect for others to train them to share the social responsibility where they live. It does not mean that other characters are not important, but by expressing a sense of responsibility and respect for others will reduce the sense of selfishness and selfishness that generally has a lot of para koruptor owned.

Learning modules are instructional materials that are arranged systematically and interestingly that includes the content of the material, methods, and evaluations that can be used independently to achieve the expected competencies [3]. While Vembriarto, states that a learning module is a teaching package that contains a unit of concepts rather than learning material [4] The module has several characteristics which consist of 1) self-instructional, selfcontained, 3) stand-alone, 4) adaptive, and 5) user-friendly [5]. The module writing structure [5] as follows: (1) opening section, consisting of title; table of contents; information map; competency goals and pretest, (2) core section, consisting of preface, relationship with other 
material or lessons, subject description, assignment and summary, and (3) closing section, consisting of glossary of terms, posttest and index.

Digital modules here are learning modules that are packaged in digital form or using computer devices that innovate in the appearance of images, videos, audio, tutorials, and evaluations in the form of quizzes that can directly display student test results. The interactive element in the digital module is a button that directs students to the available material menu choices, in addition to that there is a quiz that can directly display student test scores.

The VCT digital module referred to here is a digital module developed based on the Value Clarification Technique or VCT learning model. VCT is a learning technique to shape students in finding and determining a value that is considered good in dealing with a problem through the process of analyzing existing values and embedded in students [6]. VCT is a value clarification method in which students are not told to memorize the values that have been selected but are helped to find, choose, analyze, account for, develop, take a stand and practice the values of their own lives. Several ways regarding value learning techniques, including: (1) self-evaluation techniques and group evaluations, (2) lecturing techniques, (3) interesting and piloting techniques, (4) Indoctrination and habit standardization techniques, (5) question and answer techniques, (6) techniques for assessing writing material, both from books and special writings made by educators, (7) techniques for revealing values through games, and (8) value inquiry techniques [7].

\section{Methods}

VCT digital module was developed using the development model of Borg and Gall. The 10 steps development model by Borg and Gall are as follows : (1) research and information collecting, (2) planning, (3) develop preliminary form of product, (4) preliminary field testing, (5) main product revision, (6) main field testing, (7) operational product revision, (8) operational field testing, (9) final product revision, and (10) dissemination and implementation [8]. This study is limited to only the fifth stage. This research will continue to the next stage in other research opportunities. The following are the steps taken and the resulting output:

Table 1. The Steps and resulting output.

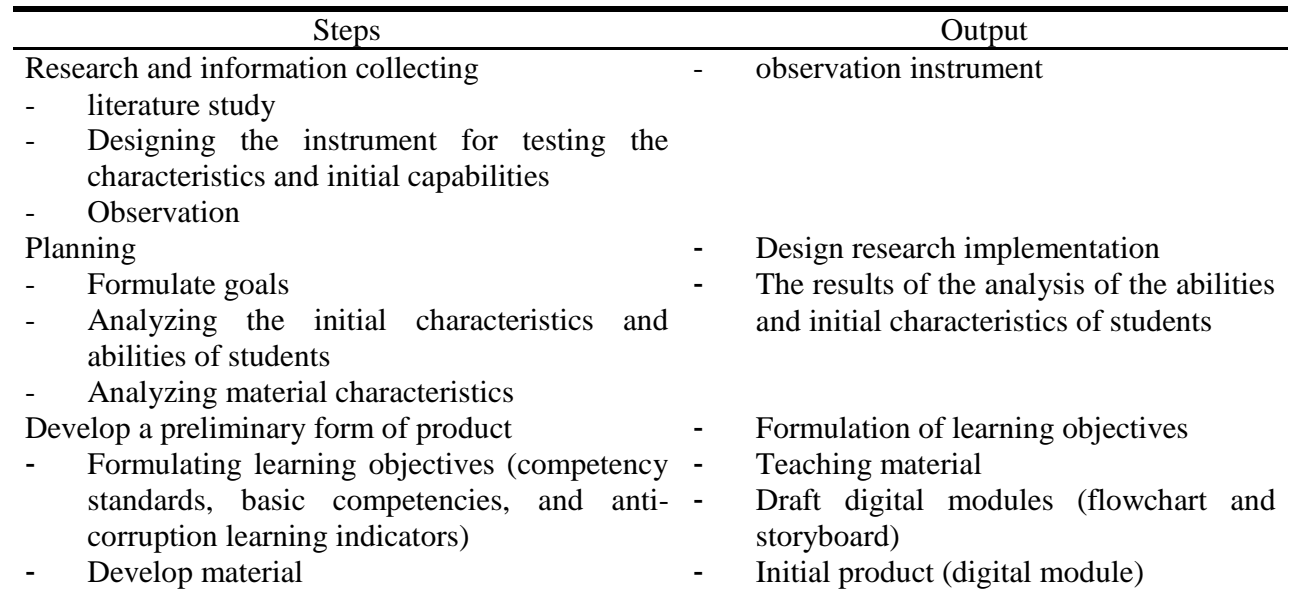


- Design a learning module flowchart and storyboard

- $\quad$ Making digital modules

- Compiling usage guidelines

- Developing media validation instruments

- Develop anti-corruption learning tools

- Develop instruments of anti-corruption learning outcomes

- Develop an anti-corruption attitude questionnaire

- Develop a questionnaire towards the learning module

- Test instrument validation

- Module validation (initial product)

Preliminary field testing

- Pretest

- Treatment

- Posttest

- $\quad$ analysis of trial results

Main product revision

- Evaluation of the results of field trials I

- Module revision
Module usage guide

Instrument learning module validation

- Expert validation results for the initial product

- Instrument validation results

- Anti-corruption learning tools

Anti-corruption learning outcomes instruments

The anti-corruption attitude questionnaire instrument

The digital module questionnaire instrument

- Anti-corruption learning outcomes

- The results of the anti-corruption attitude questionnaire

- Module questionnaire results

- Results of the evaluation of field trials I

Digital Modules revision

At the limited trial stage, the digital module was tested on 15 samples of students, which is conducted in the Department of Social Sciences, Faculty of Social Sciences UNIMED. The test instruments in the form of learning outcomes tests and questionnaires. Learning outcomes tests are used to see whether there is an increase in student learning outcomes. while the questionnaire instrument to obtain student assessments of the digital modules used. Before carrying out the treatment first, learning tools such as syllabus, lesson plans, and lecture contracts are prepared which are integrated with the VCT learning modules. Next, prepare the sources, tools, and materials needed for each treatment.

\section{Results and discussion}

The learning models designed in implementing the digital VCT module are summarized in the following table:

Table 2. Implementation of Learning Models using the Digital VCT Module

\begin{tabular}{cccll}
\hline Stage & phase & \multicolumn{1}{c}{ lecturer activities } & \multicolumn{1}{c}{ Students activities } \\
\hline Opening & $\begin{array}{c}\text { Self- } \\
\text { evaluation }\end{array}$ & - & $\begin{array}{l}\text { the module provides several } \\
\text { topics to choose from as a } \\
\text { subject matter } \\
\text { give students time to }\end{array}$ & $\begin{array}{l}\text { Choose a topic } \\
\text { convey ideas and ideas about the } \\
\text { chosen topic and the reasons for } \\
\text { choosing the topic }\end{array}$
\end{tabular}

question and answer and brainstorm ideas about each group's chosen topic 


\begin{tabular}{|c|c|c|c|}
\hline & Lecturing & $\begin{array}{l}\text { - The lecturer guides students } \\
\text { to review the material } \\
\text { outline through modules } \\
\text { The lecturer guides students } \\
\text { in understanding the } \\
\text { discussion signs and } \\
\text { assignments that students } \\
\text { must complete } \\
\text { - Guiding discussion }\end{array}$ & $\begin{array}{l}\text { - read and review the material } \\
\text { outline and discussion guidelines } \\
\text { through digital modules }\end{array}$ \\
\hline \multirow[t]{2}{*}{ Core } & example & $\begin{array}{l}\text { - Guiding students to find } \\
\text { examples from students or } \\
\text { the wider community } \\
\text { through digital modules } \\
\text { Guiding and directing } \\
\text { students in making } \\
\text { conclusions on the analysis } \\
\text { and assessment of examples } \\
\text { through digital modules }\end{array}$ & $\begin{array}{l}\text { - Discuss in groups to find } \\
\text { examples in everyday life } \\
\text { - Analyzing and evaluating } \\
\text { examples in digital modules }\end{array}$ \\
\hline & Indoctrination & $\begin{array}{l}\text { convey the values that should be } \\
\text { believed and practiced by } \\
\text { students }\end{array}$ & hear the explanation \\
\hline \multirow[t]{2}{*}{ Closing } & Dialogue & $\begin{array}{l}\text { Provide opportunities for } \\
\text { students to give questions, } \\
\text { comments and their opinions } \\
\text { about the material and the values } \\
\text { contained }\end{array}$ & $\begin{array}{l}\text { - Provide questions, responses and } \\
\text { opinions on the material and values } \\
\text { contained }\end{array}$ \\
\hline & assignment & $\begin{array}{l}\text { Provide opportunities for } \\
\text { students to conclude their } \\
\text { learning and the values contained } \\
\text { therein } \\
\text { Assign the task of evaluating an } \\
\text { article through a digital module }\end{array}$ & $\begin{array}{l}\text { - Reflect on the material that has been } \\
\text { learned and the values that are } \\
\text { believed, and determined to practice } \\
\text { the values that have been learned } \\
\text { doing homework }\end{array}$ \\
\hline
\end{tabular}

Learning plans are made by integrating the use of VCT digital modules. The learning plan made is based on the applicable provisions in the PPKn FIS UNIMED Department, which broadly includes the following components: (1) learning objectives, (2) learning materials, (3) learning methods, (4) learning resources, and (5) assessment. Learning objectives are arranged according to the syllabus of the Citizenship Education course specifically on anticorruption material. Learning materials are arranged based on needs.

The material covered is more for examples that can be understood and seen by students such as corruption cases whose news is widespread in the mass media. Furthermore, the learning method used is a modification of the model that integrates the VCT and Digital Module models. Because the digital module used is based on VCT, the steps of the learning model developed are also influenced by the VCT learning model. Related to learning resources, students can use learning resources from anywhere. In addition to textbooks, students can use resources that have been suggested in a digital module, or other sources from the library or the internet. In the learning process, some of the lecturers' roles are replaced by modules, as in the initial opening stages.

The lecturer no longer conveys the learning objectives, big-picture material, discussion guidelines, and other learning instructions because they are already in the module. Besides, the 
assessment carried out is also module based. Modules provide interactive tests. Students can immediately know the extent of their understanding of the material.

\section{Conclusion}

Preliminary tests were conducted on 15 students who were selected by purposive sampling. Selected students are students who are undergoing Civics courses. The treatment was carried out during 2 meetings for Anti-Corruption material. Before the implementation of the treatment, students were given a pretest to find out the student's initial learning outcomes. After the treatment, the students were given a posttest to review their learning outcomes and at the same time, we're given a questionnaire to give an opinion on the digital VCT module used.

Based on the results of the pretest and posttest obtained, it was found that student learning outcomes increased by $19.2 \%$.

\section{References}

[1] M. Montessori, "Pendidikan Antikorupsi sebagai Pendidikan Karakter di Sekolah," J. Demokr., vol. 11, no. 1, pp. 293-302, 2012.

[2] D. Kesuma, Korupsi dan Pendidikan Antikorupsi. Bandung: Aulia Press, 2008.

[3] I. Anwar, Pengembangan Bahan Ajar. Bandung: Direktori UPI, 2010.

[4] Vembriarto, Pengantar Pengajaran Modul. Yogyakarta: Paramita, 1987.

[5] D. T. Kependidikan, Penulisan Modul. Direktorat Tenaga Kependidikan, 2008.

[6] W. Sanjaya, Strategi Pembelajaran Berorientasi Standar Proses Pendidikan. Jakarta: Kencana, 2013.

[7] H. A.-L. Ichas and T. I. Ichas, Pengembangan Pendidikan Nilai dalam Pembelajaran Pengetahuan Sosial di Sekolah Dasar. Jakarta: Dirjendikti, 2006.

[8] N. S. Sukmadinata, Metode Penelitian Pendidikan. Bandung: Remaja Rosdakarya, 2015. 